Article

\title{
Perceptions of Future Employees toward CSR Environmental Practices in Tourism
}

\author{
Diana Corina Gligor-Cimpoieru ${ }^{1, *}$, Valentin Partenie Munteanu ${ }^{1}$, Renata Dana Niț-Antonie ${ }^{2}$, \\ Andreia Schneider ${ }^{1}$ and Gheorghe Preda ${ }^{2}$ \\ 1 Management Department, Faculty of Economics and Business Administration, West University of Timisoara, \\ Timișoara 300223, Romania; valentin.munteanu@e-uvt.ro (V.P.M.); andreia.schneider@e-uvt.ro (A.S.) \\ 2 Marketing and International Economic Relations Department, Faculty of Economics and Business \\ Administration, West University of Timișoara, Timișoara 300223, Romania; renata.nitu@e-uvt.ro (R.D.N.-A.); \\ gheorghe.preda@e-uvt.ro (G.P.) \\ * Correspondence: diana.gligor@e-uvt.ro; Tel.: +40-256-592-569
}

Received: 24 July 2017; Accepted: 8 September 2017; Published: 13 September 2017

\begin{abstract}
Corporate social responsibility (CSR) in tourism, with its central evironmental dimension, represents an important component for the sustainable growth of the tourism industry. The related CSR education could prove a major factor for future professional performance in this field of activity. Thus, this article is aimed at identifying the perceptions of current business students about CSR (students from study programs dedicated to business administration in tourism) and the importance they attribute to CSR environmental practices, mainly from their perspective as future employees in the tourism industry. We elaborated a research methodology based on the Ecolabelling principles, designed by the European Union in 2009. Our findings revealed that business tourism students assign more importance to several specific CSR environmental practices and that the importance of these CSR practices is statistically significant (we determined this significance by using the Friedman, Paired-Samples t-, ANOVA, Kruskal-Wallis and Bartlett sphericity statistical tests). The elaborated research methodology proved to be statistically highly reliable. Results also show the differences regarding the CSR practices preferred by various categories of students according to their study levels and gender. Our results pointed out that our third-year bachelor students showed a higher interest in CSR practices related to their professional training, while students from the master level degree attached more importance to CSR practices related to the environment. We also confirmed conclusions of previous studies that female respondents attach more importance to environmental issues than male respondents. Thus, we can state that a higher level of education is a key factor that supports CSR development in practice. Also, a significant conclusion of our research is related to the academic curricula for business faculties which must incorporate solid CSR and business ethics-dedicated courses and offer the needed support for the development of thematic projects about CSR Environmental practices in hotels.
\end{abstract}

Keywords: Corporate Social Responsibility; tourism; CSR environmental practices; CSR strategic approach; future employees

\section{Introduction}

In an ever-changing world, maintaining a competitive position becomes a task increasingly challenging, with the tourism industry being one of the most pressured ones to keep up with various changes and demands from different organizational stakeholders [1]. For the most part, this is due to its massive use of natural resources and exponential development in recent decades [2]. In this context, especially within an emerging knowledge based economy, tourism employees represent a particular category of stakeholders that could have a significant impact on the successful implementation of 
measures aimed at building a sustainable tourism industry [3]. Assessing values and expectations of current and future tourism employees becomes a valuable tool for tourism management [4] in the attempt of gaining the support of employees for implementing various measures, including ones dedicated to corporate social responsibility (CSR) initiatives. Among these, the CSR programs aimed at reducing the impact that tourism has on the natural environment or inpromoting a socially responsible behaviour in local communities play an important part.

With this research, our interest was focused on evaluating how various components of CSR in tourism, mainly related to protecting the natural environment, are perceived by our tourism business students from their perspective as future employees in this field of activity. Anticipating future expectations of young tourism's human resources might lead to effective and efficient measures in the field of CSR implementations, as their involvement is crucial to the success of CSR programs [3]. This particular category of young, energetic employees has the potential of becoming the key element and a vector for change in order to attain significant results in CSR activities and improve the overall business performance. Furthermore, in a strategic approach to CSR, where social and business objectives are aligned, and where social initiatives are related to the main activity of the implementing business organisations, CSR programs dedicated to employees can provide significant benefits in a win-win perspective. As previously noticed, past research has tended to neglect the implications of CSR activities on the employee's professional performances, while it can be proven that CSR can play a pivotal role in employees' identification with the employer and job satisfaction, and thus to job performance [5].

With a theoretical background of at least seven decades for the CSR concept, a significant gap can still be noticed between its theoretical development and its practical use. Although there is a significantly growing body of literature about CSR, in practice business organisations often find it yet difficult to implement CSR initiatives or lack the motivation to do so, with tourism being signalled as one of the economic sectors where CSR initiatives seem quite difficult to be put in practice [1].

This article provides new additional data about the perceptions related to CSR implementation in tourism and about the CSR's possible future implications in this field of economic activity that will be reshaped to better respond to stakeholder's expectations. At the same time, our article proposes a new research methodology for analysing perceptions of an essential category of internal stakeholders engaged in CSR implementation (namely employees).

The structure of this article includes first a theoretical background, where the main aspects about CSR in tourism and results of previous studies about the business student's perceptions toward CSR are analysed, followed by a second part where our proposed research methodology is described, and then, finally, the research results and their implications are presented.

\section{Theoretical Background}

\subsection{CSR in Tourism}

During the past decades, tourism has been reshaped or developed taking into consideration various CSR-related aspects, mainly related to the impact that tourism has on the natural environment. Thus, ecotourism, sustainable tourism or alike concepts began to be promoted both in theory and in practice. This is understandable from our perspective due to how clients perceive these kinds of activities, and as several authors [6-10] underlined, CSR activities related to environmental protection are among the most appreciated CSR initiatives, with existing willingness from tourists to pay extra for tourism services that are environmentally conscious.

Internationally, CSR initiatives exist, such as the Global Compact initiative, but we could notice that among the companies taking part voluntarily in this initiative, tourism companies only represent $2 \%$ of them. CSR implementation in tourism takes time, for example, a research conducted amongst UK tour operators [11] found that travel companies have implemented socially responsible tourism practices very slowly. 
Based on a qualitative study of the perceptions and experiences of hotel managers in Spain who have already adopted one or more environmental tools, Ayuso [12] analysed the general meaning attributed to the sustainable tourism concept and the practical applications of different voluntary environmental practices. Among others, they reached the conclusion that the questioned hotel managers had "a confused understanding of the sustainable tourism concept" [12] and they were not aware of the contribution their business was having to environmental sustainability. This is particularly important since management awareness for environmental issues was found to be a key driver for applying environmental tools.

Merwe and Wöcke [2] analysed the notion of "responsible tourism" in the case of the South African hotels, and underline the fact that there is still a "limited uptake" of CSR initiatives among these hotels, mostly due to "confusion about what the concept means, and a lack of awareness of such initiatives".

Krambia-Kapardis and Neophytidou [4] reached the conclusion that CSR-associated reporting within tourism will grow in the near future as it will be perceived as a valuable tool for gaining a competitive advantage. The perceptions about the notion of CSR within the hotel industry were explored, and the potential benefits offered by CSR reporting in this industry were documented (CSR reporting can contribute to the decrease of the operating costs in hotels, to product differentiation and to the enhancement of the hotels' brand image). Thus, hotels can attract more customers, provide better products, have a contribution to the formation of sustainable tourism destinations and improve their overall efficiency.

De Grosbois [13] evaluated the CSR reporting practices among the 150 largest hotels in the world. The research was based on a content analysis of the websites and reports published online. The used communication methods as well as the scope of reported information were identified within the study. Specifically, the author demonstrated that while many large hotels report an engagement to CSR goals, a much smaller number of them actually provide specific details of the initiatives undertaken to contribute to these goals and even less of them report that actual CSR performance was really achieved. The study also identified several challenges in the attempt to meaningfully compare CSR performances of hotel groups that report it, including issues such as the different methodologies applied for CSR evaluation and reporting, or the lack of clarity in CSR reporting.

Simões, Carvalho and Marques [14] addressed the issue of municipalities that, under budget constraints, refuse collection services (on the particular case of Portugal), this aspect having the potential to impact also the tourism industry.

Coles, Fenclova and Dinan [1] elaborated a critical review of the recent progress of the CSR research about its implementation in tourism and set possible ideas and directions for future studies. The authors reached the conclusion that in comparison to other "well established, empirically-grounded body" of CSR knowledge related to other sectors of economic activity, research dedicated to CSR in travel and tourism is still at a relatively early stage. Along the past decade, they noticed, CSR in tourism has been the primary subject of just a limited number of studies usually from a small academic community. These studies have mainly focused on three topics: implementation of CSR, the economic rationale for CSR and the social relations associated to CSR. At the same time, the authors acknowledged that the interest given to responsibility is nevertheless growing. They reached the conclusion that in order for CSR in tourism-related research to progress, a greater critical engagement with mainstream CSR thinking is required. At the same time, a greater conceptual and methodological sophistication is needed.

Camilleri [15] linked the CSR paradigms with the sustainability agenda. Based on this view, the main objective of CSR tourism implementation is to sharpen the strategic base of responsible behaviour in tourism business organisations. Obtained results suggested that long-term sustainability can be reached if practitioners in various industries successfully address societal and community deficits along with business-related objectives.

Oliveira, Pedro and Marques [16] made a study based on a sample of 28 prestige hotels (four- and five-star hotels) from Algarve, one of the most important travel destinations in Portugal. They used 
two models, the data envelopment analysis and stochastic frontier approach techniques, to address the issue of efficiency. The obtained results were almost similar with both these models, showing that hotel companies could significantly reduce their inputs while maintaining the same level of outputs. Siu-wa Chan [17] aimed at investigating the perceptions of hotel customers regarding different green marketing strategies. A 30 statements questionnaire was used to evaluate respondents' perceptions. By using an exploratory factor analysis, five relevant factors have been identified and interpreted: "Green Partnership", "Development of Green Products and Services", "Genuine Green Products and Services", "Higher Price for Green Products" and "Services and Credibility of Green Promotion".

Wells et al. [3] explored a consolidative model of CSR, focusing mainly on the employees' but also the visitors' viewpoints, in a large heritage tourism organisation. The conducted research located the analysed organisations within a three-phase model and noted that different parts of an organisation might be attending various stages of CSR implementation.

Fatma, Rahman and Khan [18] developed a new scale to measure consumers' perceptions about CSR activities in the tourism industry. A qualitative research has been carried out to generate a pool of items, and various reliability and validity tests have been carried out to confirm a scale structure. Results led to a three-dimensional 18-item scale for measuring consumer perception about CSR activities in the tourism industry. This study contributed to the existing CSR literature by offering a comprehensive framework based on a sustainable development approach for measuring consumers' perceptions about CSR activities.

Research has shown that CSR initiatives may play a crucial role in improving customer-company relationships, and thus that companies should perceive CSR initiatives from a relationship marketing perspective, with CSR being a major factor for establishing trust [19].

\subsection{Perceptions of Business Students toward CSR}

Past decades have brought an abundance of CSR-related research, with several studies analysing the perception of students toward CSR, but only very few of them investigated the attitude of students toward CSR from their perspective as future employees in various fields of economic activity.

Sobczak, Debucquet and Havard [20] in an exploratory study examined the impact of the French educational system on the CSR-related perceptions of students and young managers (alumni). The authors underlined that there is a need for higher education institutions to integrate CSR into their culture.

Wong, Fu Long and Elankumaran [21] applied simultaneously a survey in America, China and India on a sample consisting of 317 business students and the aim of the study was to identify differences in the business students' CSR perceptions. Their evaluation instrument was based on Likert scales for 12 CSR situations that students might encounter if holding management positions. The most significant differences identified by this research were that the U.S. and Indian business students considered the noneconomic aspects of CSR more important than the Chinese students and also that the Indian business students emphasised philanthropy as a more important CSR element, while US business students pointed out legal obligations as being more important. Authors pointed out that these results have implications for academic curriculum, public policies and multinational companies.

Evans and Davis [22] investigated how perceptions about corporate citizenship can impact job attractiveness. They tested six hypotheses on 141 students using a questionnaire that they developed using items on a seven-point Likert scale. Their findings revealed that individuals with CSR education perceived corporate citizenship as having a greater impact on job attractiveness.

Burcea and Marinescu [23] conducted research aimed at investigating the perceptions of students about their level of CSR knowledge and the applicative impact of the CSR concept. They constructed a questionnaire and applied it to a sample consisting of 400 business students. Their results revealed that students attach importance to CSR at the academic level, that they are interested in CSR projects, being involved in many CSR activities to protect the natural environment and to develop local communities.

Probably one of the most relevant previous studies for our research was conducted by Del Mar Alonso-Almeida [24] who aimed at identifying differences in CSR perceptions between tourism 
students and managers in Madrid, emphasising attitudes toward environmental issues from a gender perspective. The first sample consisted of 197 tourism students who attended tourism courses at the university and 409 restaurant managers represented the second sample. The obtained results showed that women are more concerned about environmental issues than men, both in the students and managers sample. In the end, these findings can provide support for new evidence about "tourism education and eco-feminist theories".

Fitzpatrick and Cheng [25] examined how the CSR perceptions might be explained by culture, gender and spirituality from the business students' point of view. For this, 233 undergraduate-level business students from the United States and Hong Kong were interviewed. Their research findings revealed that "spirituality is related to CSR perceptions" and that "women exhibit greater sensitivity to CSR and ethics than men".

A study developed by Yilmazdogan, Secilmis and Cicek [26] on a sample of 565 tourism students examined how the CSR activities of a hotel can influence the perceptions of tourism students when searching for a working place. Results revealed that the CSR activities of a hotel influenced the students' intentions to work for a certain employer in the tourism sector. Also, they pointed out that there "is a significant and positive-oriented relationship between CSR's sub-dimensions of ethical responsibility, philanthropic, legal responsibility and economic responsibility".

Barrena-Martinez et al. [27] conducted a research with the purpose of analysing the students' perceptions when choosing a socially responsible organisation for which to work. They investigated the possibility that conflicts might arise between the students' values and the organisational values of the employer by analysing a sample consisting of 1596 students from 9 Spanish Universities. The authors considered that CSR is used more and more as a strategic management tool to attract potential employees and that the attitude of students related to CSR is determined by knowledge, gender and maturity.

In conclusion, we can state that previous studies addressed the issues of CSR implementation in tourism, most of them identifying difficulties or delays when compared with other economic sectors where CSR programs have been implemented.

Regarding the previous studies about the students' perception about CSR, we can conclude that students attach a certain importance to CSR-related issues, and CSR and Business Ethics topics should represent a more significant component in the academic curricula of tourism business schools.

\section{Data Collection and Research Methodology}

The main objective of our research was to evaluate the perception that tourism students have about CSR environmental practices from their perspective as future employees in the tourism industry.

For the measuring scales, we elaborated a research instrument (questionnaire) starting from the directions provided by the Ecolabel for hotels promoted by the European Union (2009) [28]. Based on this, eight "Environment dimensions" were identified as relevant for our "Environment" construct and several items were set for each of these environmental dimensions (presented in Table 1, a synthesis table, in the first and second columns). To measure the importance given to environmental CSR practices when considering future hiring options by tourism graduating students, we have used a five-item Likert scale (where 5 is attributed to "Very important", and 1 is attributed to "Unimportant").

The total statistical population for our research consisted of 191 business administration students (represented by the total number of students enrolled in tourism specialisations at the largest business faculty from a public university from Timișoara). West University of Timișoara, Romania, where the study was conducted, represents the largest university from this region and the fourth at a national level. 
Table 1. Means, standard deviations and confirmatory factor analysis.

\begin{tabular}{|c|c|c|c|c|c|c|c|}
\hline \multirow{2}{*}{$\begin{array}{l}\text { Environment } \\
\text { Dimension }\end{array}$} & \multirow{2}{*}{ Items } & \multirow{2}{*}{ DM } & \multirow{2}{*}{ IM } & \multirow{2}{*}{ SD } & \multicolumn{3}{|c|}{ Confirmatory Factor Analysis } \\
\hline & & & & & KMO & BTSL & FL \\
\hline \multirow{5}{*}{$\begin{array}{l}\text { Responsible } \\
\text { energy } \\
\text { consumption }\end{array}$} & Use of appropriate thermal insulation & \multirow{5}{*}{3.86} & 4.14 & 0.981 & \multirow{4}{*}{0.814} & \multirow{4}{*}{0.0} & 0.828 \\
\hline & $\begin{array}{l}\text { Use of electricity from renewable energy } \\
\text { sources }\end{array}$ & & 4.01 & 1.119 & & & 0.831 \\
\hline & $\begin{array}{l}\text { Use of automated closures of light, } \\
\text { electronics, heating, etc. }\end{array}$ & & 3.92 & 1.097 & & & 0.866 \\
\hline & $\begin{array}{l}\text { Collecting data about energy } \\
\text { consumption }\end{array}$ & & 3.71 & 1.064 & & & 0.849 \\
\hline & $\begin{array}{l}\text { Use of electrical appliances with high } \\
\text { energy efficiency* }\end{array}$ & & 3.55 & 1.076 & - & - & - \\
\hline \multirow{5}{*}{$\begin{array}{l}\text { Responsible water } \\
\text { consumption }\end{array}$} & Appropriate linen and towels change & \multirow{5}{*}{3.99} & 4.52 & 0.840 & \multirow{5}{*}{0.788} & \multirow{5}{*}{0.0} & 0.759 \\
\hline & Wastewater correctly treated & & 4.18 & 1.108 & & & 0.847 \\
\hline & $\begin{array}{l}\text { Collecting data about water } \\
\text { consumption }\end{array}$ & & 3.85 & 1.001 & & & 0.689 \\
\hline & $\begin{array}{l}\text { Use washing machines/dishwashers, } \\
\text { toilets etc. with a low water } \\
\text { consumption }\end{array}$ & & 3.83 & 1.128 & & & 0.849 \\
\hline & $\begin{array}{l}\text { Reduced water flow for taps and } \\
\text { showers }\end{array}$ & & 3.58 & 1.193 & & & 0.811 \\
\hline \multirow{4}{*}{$\begin{array}{l}\text { Responsible waste } \\
\text { management }\end{array}$} & $\begin{array}{l}\text { Separation and proper disposal of } \\
\text { hazardous waste }\end{array}$ & \multirow{4}{*}{4.22} & 4.38 & 0.971 & \multirow{4}{*}{0.804} & \multirow{4}{*}{0.0} & 0.895 \\
\hline & Waste separation (selective waste) & & 4.26 & 0.992 & & & 0.881 \\
\hline & Appropriate waste disposal & & 4.20 & 0.922 & & & 0.813 \\
\hline & $\begin{array}{l}\text { Avoid single-use products and } \\
\text { environmental hazardous products }\end{array}$ & & 4.06 & 1.110 & & & 0.893 \\
\hline \multirow{3}{*}{$\begin{array}{c}\text { Responsible } \\
\text { management of } \\
\text { chemical } \\
\text { hazardous } \\
\text { substances }\end{array}$} & Proper use of chemical substances & \multirow{3}{*}{4.01} & 4.36 & 0.933 & \multirow{3}{*}{0.734} & \multirow{3}{*}{0.0} & 0.894 \\
\hline & $\begin{array}{l}\text { Collecting data about chemical } \\
\text { substances consumption }\end{array}$ & & 3.88 & 1.009 & & & 0.871 \\
\hline & $\begin{array}{l}\text { Use of only certain paints, varnishes and } \\
\text { detergents with Ecolabelling }\end{array}$ & & 3.81 & 1.132 & & & 0.891 \\
\hline \multirow{4}{*}{ Green acquisitions } & $\begin{array}{l}\text { Use of highly efficient equipment (both } \\
\text { energy and water consumption) }\end{array}$ & \multirow{4}{*}{3.76} & 3.86 & 1.110 & \multirow{4}{*}{0.794} & \multirow{4}{*}{0.0} & 0.856 \\
\hline & Use of eco-labelled products & & 3.84 & 1.053 & & & 0.886 \\
\hline & $\begin{array}{l}\text { Reusable glass bottles are used in } \\
\text { common practice }\end{array}$ & & 3.75 & 1.132 & & & 0.795 \\
\hline & $\begin{array}{l}\text { No single-use products in common } \\
\text { practice: bottles, glasses, plates or } \\
\text { cutlery, etc. }\end{array}$ & & 3.58 & 1.192 & & & 0.765 \\
\hline \multirow{4}{*}{$\begin{array}{l}\text { Employee training } \\
\text { for environment } \\
\text { protection-related } \\
\text { issues }\end{array}$} & $\begin{array}{l}\text { Staff training on effective waste } \\
\text { management, saving energy and } \\
\text { other resources* }\end{array}$ & \multirow{4}{*}{4.15} & 4.63 & 0.607 & - & - & - \\
\hline & $\begin{array}{l}\text { Staff training on the good maintenance } \\
\text { and servicing of equipment }\end{array}$ & & 4.03 & 1.033 & & & 0.894 \\
\hline & $\begin{array}{l}\text { Staff training on the correct dosage of } \\
\text { detergents and cleaning products }\end{array}$ & & 4.01 & 1.025 & 0.739 & 0.0 & 0.930 \\
\hline & Staff training on environment protection & & 3.93 & 1.038 & & & 0.940 \\
\hline & Arranging smoking areas * & & 4.28 & 1.094 & - & - & - \\
\hline & Offering local and bio foods & & 3.95 & 1.076 & & & 0.775 \\
\hline $\begin{array}{l}\text { Operational } \\
\text { services related to }\end{array}$ & $\begin{array}{l}\text { EMAS (Eco-Management and Audit } \\
\text { Scheme) registration or } \\
\text { ISO } 14001 \text { certification }\end{array}$ & & 3.87 & 1.152 & & & 0.802 \\
\hline $\begin{array}{c}\text { environment } \\
\text { protection }\end{array}$ & $\begin{array}{l}\text { Use of local heating system, energy } \\
\text { recovery or combined heat }\end{array}$ & 3.82 & 3.85 & 1.150 & 0.898 & 0.0 & 0.844 \\
\hline & Obtaining a national eco-label & & 3.79 & 1.076 & & & 0.878 \\
\hline & Use of photovoltaic and wind energy & & 3.75 & 1.125 & & & 0.853 \\
\hline & Bioclimatic architecture & & 3.55 & 1.122 & & & 0.832 \\
\hline & Use of rainwater and recycled water & & 3.54 & 1.107 & & & 0.845 \\
\hline
\end{tabular}


Table 1. Cont.

\begin{tabular}{|c|c|c|c|c|c|c|c|}
\hline \multirow{2}{*}{$\begin{array}{l}\text { Environment } \\
\text { Dimension }\end{array}$} & \multirow{2}{*}{ Items } & \multirow{2}{*}{ DM } & \multirow{2}{*}{ IM } & \multirow{2}{*}{ SD } & \multicolumn{3}{|c|}{ Confirmatory Factor Analysi } \\
\hline & & & & & KMO & BTSL & FL \\
\hline \multirow{5}{*}{$\begin{array}{l}\text { Informing clients } \\
\text { about environment } \\
\text { protection-related } \\
\text { issues }\end{array}$} & $\begin{array}{l}\text { Providing information about local } \\
\text { public transportation * }\end{array}$ & \multirow{5}{*}{3.98} & 4.37 & 0.879 & - & - & - \\
\hline & $\begin{array}{l}\text { Providing information about saving } \\
\text { water and energy }\end{array}$ & & 3.94 & 1.087 & \multirow{4}{*}{0.788} & \multirow{4}{*}{0.0} & 0.850 \\
\hline & $\begin{array}{l}\text { Providing information about } \\
\text { waste separation }\end{array}$ & & 3.94 & 0.964 & & & 0.871 \\
\hline & $\begin{array}{l}\text { Providing information about } \\
\text { environmental protection measures to be } \\
\text { taken during the accommodation period }\end{array}$ & & 3.88 & 1.086 & & & 0.896 \\
\hline & $\begin{array}{l}\text { Providing information aboutlocal events } \\
\text { and news relating to the } \\
\text { environment protection }\end{array}$ & & 3.78 & 0.927 & & & 0.794 \\
\hline
\end{tabular}

Notes: DM = Dimension mean; IM = Item mean; SD = Standard deviation; KMO = Kaiser-Meyer-Olkinindicator BTSL = Bartlett test significance level; FL = Factor loadings. * These items were eliminated in the stage reliability analysis for the measuring scales in order to increase the calculated Alpha Cronbach value and thus assuring a higher reliability of the research instrument.

The questionnaire used was organized in two parts: one dedicated to CSR environmental practices and another to the profile of the respondents. In the section for the evaluation of CSR environmental practices 38 items were used and eight sub-dimensions were set (responsible energy consumption, responsible water waste, responsible waste management, responsible management of chemical hazardous substances, green acquisitions, employee training for environment protection-related issues, operational services related to environment protection and informing clients about environment protection-related issues). For defining the profile of the respondents, five items were used in the questionnaire, addressing the aspects of the year of study, gender, the type of the home environment, if respondents are employed and if they are employed in the tourism sector.

The questionnaire was distributed in printed format or online format. We collected 120 valid questionnaires proper for statistical analysis. The data were collected during 1 month (October-November 2016), and analysed using a statistical analysis software package, SPSS 23.0.

As a sample construction, we used convenience sampling technique. Our sample of respondents included only students from the second-year bachelor degree (that represented $27.5 \%$ of the sample) and higher, as the second year of studies is when the mandatory discipline of Business Ethics is studied. Third-year bachelor degree represented $32.5 \%$ of our sample, first-year master degree students represented $13.3 \%$ of it, and second-year master degree students represented $26.7 \%$ of the total number of respondents. We noticed an uneven distribution between urban and rural residence students (approximately 6 out of 10 respondents live in an urban area) and a higher gap between the number of female respondents (over $83 \%$ of the total sample) and male respondents (less than $17 \%$ of the total sample).

Specifically, the following research steps were designed, corresponding to the various stages of our research:

(I) Determining students' perception regarding the importance given to CSR environmental practices when considering their future hiring options in the tourism industry; to test that each of the practices identified as being the most important one for each environmental dimension (according to the calculated means, presented in a synthesis table) we have used the Friedman test. Results of this test can prove if there are overall significant differences from a statistical point of view between the perceptions of students for these practices and the $\chi^{2}$ (Chi-Square) calculated value associated with Friedman's test that shows a certain level of significance. Furthermore, to compare the importance associated to the two CSR practices with the highest means for each dimension (shown in the synthesis table as the first two lines for each environmental dimension), we have used the Paired-Samples $t$-test to identify whether or not the CSR environmental practice with the highest mean is statistically more important than the rest of the practices included in that dimension; 
(II) Making an analysis of these students' perception about the importance of CSR environment practices based on defined profile variables (year of study, gender and area of residence); with this analysis we aimed at identifying the existence of statistically significant differences between several categories of respondents: (1) differences between the perception of students from various years of study (using the ANOVA and the Kruskal-Wallis tests). After applying the ANOVA test we used the Bonferroni test to identify the sub-sample pairs between which there is a statistically significant difference, and after applying the Kruskal-Wallis test we used the Mann-Whitney test that compares two by two the formed sub-samples; (2) differences between female and male respondents (using the Independent-Samples $t$-test) and (3) differences between students with a residence in urban or rural areas (using the Independent-Samples $t$-test);

(III) Making a reliability analysis for our measuring scales (questionnaire items); to test the reliability of our questionnaire the Alpha Cronbach indicator was used;

(IV) Analyzing the opportunity for a factor analysis and, if adequate, to conduct a confirmatory factor analysis; for this step in our research, first we have checked the opportunity for conducting a factor analysis using the Kaiser-Meyer-Olkin (KMO) indicator (that measures the intensity of the existing correlations between the items of a construct) and the Bartlett's test of sphericity (that indicates to us the existence or the non-existence of significant correlations between the items of a construct). Secondly, a confirmatory factor analysis was done (limiting the number of factors to one) for each defined environmental dimension. Finally, a factorial analysis was conducted for the entire "Environment" construct using the principal component analysis method because the entire variance of the variable was decomposed. Using the factor analysis, factor loadings were calculated for each of the defined environmental dimensions and each item included in these dimensions.

\section{Results}

Determining future employees' CSR expectations can prove useful for tourism managers as a way of anticipating priorities in CSR implementation. Means and standard deviations for each analysed environmental dimension and the items associated are presented in Table 1 (columns 3-5) shown below. Table 1 is a synthesis table, data included into it being also used in the following steps of our research. Each of the eight identified environmental dimensions obtained a general mean that indicates that these aspects are important for students, with "Responsible waste management" being considered the most important one (with a 4.22 general mean).

According to the calculated means, the most important environmental responsible practices are: "Staff training on effective waste management, saving energy and other resources" (with a 4.63 mean), "Appropriate linen and towels change" (with a 4.52 mean), "Separation and proper disposal of hazardous waste" (with a 4.38 mean), "Providing information about local public transportation" (with a 4.37 mean) and "Proper use of chemical substances" (with a 4.36 mean).

Further, in our research, we aimed at determining the most important environmental CSR practices statistically relevant using the Friedman and the Paired-Samples t-test (obtained results being presented in Table 2).

Analyzing the data provided in Table 2, we can reach the following two conclusions:

- There is not a CSR environmental practice that is statistically more important than others according to the students" perception in the "Responsible energy consumption", "Responsible waste management" and "Green acquisitions" environmental dimensions;

- The CSR environmental practices of "Appropriate linen and towels change", "Proper use of chemical substances", "Staff training on effective waste management, saving energy and other resources", "Arranging smoking areas" and "Providing information about local public transportation" are statistically the most important ones in their corresponding environmental dimensions according to the questioned tourism students. 
Table 2. Significance levels.

\begin{tabular}{|c|c|c|c|c|c|c|}
\hline Environment Dimension/CSR Practice & $x^{2}$ & SL & $\begin{array}{c}\text { SSDD } \\
\text { (YES/NO) }\end{array}$ & $\mathrm{CtV}$ & SL & $\begin{array}{c}\text { SSDP } \\
\text { (YES/NO) }\end{array}$ \\
\hline $\begin{array}{l}\text { 1. Responsible energy consumption/Use of } \\
\text { appropriate thermal insulation }\end{array}$ & 42.836 & $0.000(<0.05)$ & YES & 1.579 & $0.117(>0.05)$ & NO \\
\hline $\begin{array}{l}\text { 2. Responsible water } \\
\text { consumption/Appropriate linen and } \\
\text { towels change }\end{array}$ & 99.463 & $0.000(<0.05)$ & YES & 4.094 & $0.000(<0.05)$ & YES \\
\hline $\begin{array}{l}\text { 3. Responsible waste management/Separation } \\
\text { and proper disposal of hazardous waste }\end{array}$ & 13.976 & $0.003(<0.05)$ & YES & 1.711 & $0.090(>0.05)$ & NO \\
\hline $\begin{array}{l}\text { 4. Responsible management of chemical } \\
\text { hazardous substances/Proper use of } \\
\text { chemical substances }\end{array}$ & 47.616 & $0.000(<0.05)$ & YES & 6.541 & $0.000(<0.05)$ & YES \\
\hline $\begin{array}{l}\text { 5. Green acquisitions/Use of highly } \\
\text { efficient equipment (both energy and } \\
\text { water consumption) }\end{array}$ & 4.517 & $0.211(>0.05)$ & NO & $-*$ & $-{ }^{*}$ & $-*$ \\
\hline $\begin{array}{l}\text { 6. Employee training for environment } \\
\text { protection-related issues/Staff training on } \\
\text { effective waste management, saving energy } \\
\text { and other resources* }\end{array}$ & 63.977 & $0.000(<0.05)$ & YES & 6.266 & $0.000(<0.05)$ & YES \\
\hline $\begin{array}{l}\text { 7. Operational services related to environment } \\
\text { protection/Arranging smoking areas }\end{array}$ & 84.614 & $0.000(<0.05)$ & YES & 3.014 & $0.003(<0.05)$ & YES \\
\hline $\begin{array}{l}\text { 8. Informing clients about environment } \\
\text { protection-related issues/Providing } \\
\text { information about local public transportation * }\end{array}$ & 31.201 & $0.000(<0.05)$ & YES & 3.229 & $0.002(<0.05)$ & YES \\
\hline
\end{tabular}

Notes: $\chi^{2}=$ Calculated $\chi^{2}$ value; SL = Significance level; SSDD = Significant statistical difference for the dimension; $\mathrm{CtV}=$ Calculated $t$ value (using the Paired-Samples $t$-test); SL = Significance level; SSDP = Significant statistical difference for the practice. ${ }^{*}$ In this case the Paired-Samples $t$-test was not necessary.

Using the same pattern for research methodology as the one previously presented, an analysis was conducted at the level of the eight defined environmental dimensions, leading us to the conclusion that there is no dimension more important according to the questioned students toward other dimensions that showed high general means.

Using ANOVA and Kruskal-Wallis tests, we have identified several CSR environmental practices for which there are statistically significant differences in perceptions according to the responder's year of study (presented in Table 3).

Table 3. Statistically significant differences of perceptions according to the responder's year of study.

\begin{tabular}{lllc}
\hline \multicolumn{1}{c}{ Environment Dimension } & \multicolumn{1}{c}{ Items } & CV & SL \\
\hline Responsible waste management & $\begin{array}{l}* * \text { Separation and proper disposal of } \\
\text { hazardous waste }\end{array}$ & 8.633 & 0.035 \\
\hline \multirow{2}{*}{$\begin{array}{l}\text { Responsible management of } \\
\text { chemical hazardous substances }\end{array}$} & $\begin{array}{l}\text { ** Use of only certain paints, varnishes and } \\
\text { detergents with Ecolabelling }\end{array}$ & 8.431 & 0.038 \\
\cline { 2 - 4 } & ** Proper use of chemical substances & 10.044 & 0.018 \\
\cline { 2 - 4 } & $\begin{array}{l}* * \text { Collecting data about chemical } \\
\text { substances consumption }\end{array}$ & 8.436 & 0.038 \\
\hline Green acquisitions & $*$ Reusable glass bottles are used in common practice & 5.495 & 0.001 \\
\hline $\begin{array}{l}\text { Employee training for environment } \\
\text { protection-related issues }\end{array}$ & $\begin{array}{l}* * \text { Staff training on effective waste management, } \\
\text { saving energy and other resources }\end{array}$ & 24.887 & 0.000 \\
\hline $\begin{array}{l}\text { Operational services related to } \\
\text { environment protection }\end{array}$ & $* *$ Arranging smoking areas & 11.650 & 0.009 \\
\cline { 2 - 4 } & $*$ Use of photovoltaic and wind energy & 4.643 & 0.004 \\
\hline
\end{tabular}

Notes: $\mathrm{CV}=$ Calculated value of the indicator; $\mathrm{SL}=$ Significance level. ${ }^{*}$ Using the ANOVA test. ${ }^{* *}$ Using the Kruskal-Wallis test.

For the CSR environmental practices identified with the ANOVA test as having different levels of importance for students from different years, we further applied the Bonferroni test to determine the sub-samples for which the difference of perspective exists. Results showed us that the practice of 
"Reusable glass bottles are used in common practice" is statistically more important for the secondand first-year master students and the second-year bachelor students than for the third-year bachelor students $(p=0.005,0.039$ and $0.014<0.05)$. By using the same method, we determined that the practice of using "Use of photovoltaic and wind energy" is statistically more important for second-year master students than for third-year bachelor students $(p=0.002<0.05)$.

For the CSR environmental practices identified with the Kruskal-Wallis test as having different levels of importance for students from different years, we further applied the Mann-Whitney test and reached the conclusions that all these practices except for one ("Staff training on effective waste management, saving energy and other resources") are statistically less important for third-year bachelor students than for other categories of students. As mentioned, the CSR practice of "Staff training on effective waste management, saving energy and other resources" is more important for third-year bachelor students (Mean rank 44.76) than for second-year master students (Mean rank 25.33) ( $p=0.000$ $<0.0167)$ and for second-year bachelor (Mean rank 30.32) $(p=0.001<0.0167)$.

Using Paired-Samples $t$-test to determine differences in perception between women and men, we identified several CSR environment-related practices that were perceived differently by female and male respondents (shown in Table 4). For all the CSR practices mentioned in Table 4, we noticed that they are more important for female respondents than for male respondents, thus confirming results from other research showing that, in general, women are more sensitive about the topic of environmental issues (like for instance Del Mar Alonso-Almeida, 2013 [24] also confirmed).

Table 4. CSR Corporate Social Responsibility environment-related practices that are perceived differently by women and men.

\begin{tabular}{|c|c|c|c|c|}
\hline Environment Dimension & Items & Means & $\begin{array}{l}\text { Calculated } t \\
\text { Values }\end{array}$ & Significance Level \\
\hline $\begin{array}{l}\text { Responsible energy } \\
\text { consumption }\end{array}$ & $\begin{array}{l}\text { Use of electrical appliances with high energy } \\
\text { efficiency }\end{array}$ & $\begin{array}{l}F=3.66 \\
M=3.00\end{array}$ & 2.563 & 0.012 \\
\hline \multirow{2}{*}{$\begin{array}{l}\text { Responsible waste } \\
\text { management }\end{array}$} & Appropriate linen and towels change & $\begin{array}{c}\mathrm{F}=4.59 \\
\mathrm{M}=4.15\end{array}$ & 2.172 & 0.032 \\
\hline & Collecting data about water consumption & $\begin{array}{r}\mathrm{F}=3.93 \\
\mathrm{M}=3.45\end{array}$ & 1.981 & 0.050 \\
\hline \multirow{3}{*}{$\begin{array}{l}\text { Responsible waste } \\
\text { management }\end{array}$} & Appropriate waste disposal & $\begin{array}{l}\mathrm{F}=4.31 \\
\mathrm{M}=3.65\end{array}$ & 2.309 & 0.031 \\
\hline & $\begin{array}{l}\text { Avoid single-use products and environmental } \\
\text { hazardous products }\end{array}$ & $\begin{array}{l}\mathrm{F}=4.15 \\
\mathrm{M}=3.60\end{array}$ & 2.050 & 0.043 \\
\hline & $\begin{array}{l}\text { Separation and proper disposal of hazardous } \\
\text { waste }\end{array}$ & $\begin{array}{l}\mathrm{F}=4.49 \\
\mathrm{M}=3.80\end{array}$ & 2.244 & 0.035 \\
\hline Green acquisitions & $\begin{array}{l}\text { No single-use products in common practice: } \\
\text { bottles, glasses, plates or cutlery, etc. }\end{array}$ & $\begin{array}{l}\mathrm{F}=3.68 \\
\mathrm{M}=3.10\end{array}$ & 2.011 & 0.047 \\
\hline \multirow{5}{*}{$\begin{array}{l}\text { Employee training for } \\
\text { environment } \\
\text { protection-related issues }\end{array}$} & \multirow{2}{*}{$\begin{array}{l}\text { Staff training on the correct dosage of } \\
\text { detergents and cleaning products }\end{array}$} & $\mathrm{F}=4.11$ & \multirow{2}{*}{2.482} & \multirow{2}{*}{0.014} \\
\hline & & $\mathrm{M}=3.50$ & & \\
\hline & \multirow{2}{*}{$\begin{array}{l}\text { Staff training on effective waste management, } \\
\text { saving energy and other resources }\end{array}$} & $\mathrm{F}=4.72$ & \multirow{2}{*}{3.676} & \multirow{2}{*}{0.000} \\
\hline & & $\mathrm{M}=4.20$ & & \\
\hline & $\begin{array}{l}\text { Staff training on the good maintenance and } \\
\text { servicing of equipment }\end{array}$ & $\begin{array}{l}\mathrm{F}=4.13 \\
\mathrm{M}=3.50\end{array}$ & 2.547 & 0.012 \\
\hline \multirow{2}{*}{$\begin{array}{l}\text { Operational services } \\
\text { related to environment } \\
\text { protection }\end{array}$} & \multirow[b]{2}{*}{ EMAS registration or ISO 14001 certification } & $\mathrm{F}=3.97$ & \multirow{2}{*}{2.234} & \multirow{2}{*}{0.027} \\
\hline & & $\mathrm{M}=3.35$ & & \\
\hline
\end{tabular}

Using the same research method as in the previous case (the Paired-Samples $t$-test), we observed that there are no statistically significant differences in perceptions between respondents from an urban or rural residence.

To test the consistency of the measuring scale used, we have used the Alpha Cronbach coefficient, results being presented in Table 5. Analyzing the values obtained for the Alpha Cronbach coefficient, we can state that all the defined measuring scales are reliable, having a value above the acceptable limit of 0.7 [29]. In order to improve the reliability of the measuring scale, several items ("Use of 
electrical appliances with high energy efficiency", "Staff training on effective waste management, saving energy and other resources", "Arranging smoking areas", "Providing information about local public transportation") with lower $\alpha$ Cronbach values could be eliminated, thus having a recalculated value for the Alpha Cronbach coefficient. The final value for $\alpha$ Cronbach is 0.950 , showing a strong reliability of our designed measuring scale.

Table 5. Reliability analysis for environmental dimensions.

\begin{tabular}{cccc}
\hline \multirow{2}{*}{ Construct } & Environmental Dimensions & \multicolumn{2}{c}{$\alpha$ Cronbach } \\
\cline { 3 - 4 } & Responsible energy consumption & Initial & Final \\
\hline & Responsible water consumption & 0.847 & 0.864 \\
& Responsible waste management & 0.890 & - \\
Environment & Responsible management of chemical hazardous substances & 0.859 & - \\
$(\alpha$ Cronbach $=0.950)$ & Green acquisitions & 0.842 & - \\
& Employee training for environment protection-related issues & 0.816 & 0.911 \\
& Operational services related to environment protection & 0.919 & 0.926 \\
& Informing clients about environment protection-related issues & 0.765 & 0.875 \\
\hline
\end{tabular}

Results of the confirmatory factor analysis are presented in synthesis Table 1 (columns 6-8). We can notice that for each defined environmental dimension there are strong correlations among items with values of the KMO indicator that vary between 0.734 and $0.898(>0.7)$ and that the value for the significance Bartlett test is 0.000 . Also, all the loading factors are above the admitted minimal limit of 0.4 [30]. In these conditions, no additional questionnaire item needed to be eliminated from the analysis.

\section{Discussion and Conclusions}

Our paper analysed the perceptions of future employees in the tourism industry about the CSR environmental dimension, an important aspect that will contribute to future changes in this industry. Assessment of the perceptions that future employees have on CSR implementation can be a useful indicator for tourism managers in their decisions regarding the resources allocation for implementing CSR in tourism and when aiming for attracting valuable employees. CSR implementation in tourism faces its own particular challenges, but undertaken studies showed that environment CSR practices tend to be appreciated by organisational stakeholders, including primary ones like clients and employees.

Within our research, we noticed that third-year bachelor students showed a higher interest in CSR practices related to their professional training, thus evaluating the importance of CSR training as the most important and relevant aspect for them. Students from the second master level degree of education attached more importance to some CSR practices (reuse the plastic bottles, photovoltaic and wind energy system) than the other questioned students. Students from the second-year bachelor degree attached more importance to the distribution and separation of high-risk waste compared with other categories of students. Most CSR practices related to environmental issues are more important for master degree students than for bachelor degree students. Thus, we can state that a higher level of education is a key factor that supports CSR development in practice. Other studies [22] support our conclusion that CSR-educated individuals have a better attitude toward CSR and that CSR education can have multiple implications on curriculum developing, public policies implications and for employing multinational companies [20]. Even in the case of educational institutions that develop and teach CSR-related management tools, there is still a need to integrate CSR into the organisational culture [20].

In our analysed sample, students' gender proved to be a differential factor: environment issues related to CSR practices were perceived as more important for women, especially when considering 
their future hiring options. Thus, obtained results proved to be in accordance with results from previous researchers [24] who pointed out that, in general, female respondents are more concerned about environmental issues than male respondents, and that women exhibit greater sensitivity to CSR and ethics than men [25]. When analyzing these aspects, we need to take into consideration also other results, like for instance from a recent Spanish study aimed at analyzing the students' perception toward their criteria in choosing a socially responsible organization to work for, that concluded that students' attitude toward their future employer is determined by the potential conflicts between their personal values and the CSR organizational values [27].

Recent research supports the need for CSR implementation in tourism according to student's perception: students attach importance to CSR at an academic level, that they are interested to find details about CSR projects and a significant and positive-oriented relationship between CSR and economic responsibilities exists [27].

Our research pointed out that there are no statistically significant differences in perception between respondents with urban or rural residence.

An important emphasis conclusion of our research is that the curricula in business faculties should take into account the increasing needs of future tourism employees and managers for information about CSR practices. Preparing tourism students for a better implementation of CSR programs in practice can be achieved both by developing relevant academic curricula for this (with courses dedicated to business ethics and CSR) and by actually involving students in implementing CSR projects in the hospitality industry, so that students can acquire the ability to issue valuable judgments about CSR and gain the ability to find new solutions for employee performance at work and hotel accommodation in the field of CSR.

For tourism managers (as decision makers), our research results can be used as an argument for them to integrate into business strategies those important CSR practices regarding attractiveness for future employees. In this way, a strategic approach to CSR brings a significant contribution for attracting and retaining valuable employees.

Although the conducted reliability analysis showed good results, thus proving that a useful research tool was elaborated, our research has several limitations that future research could reduce, like the limited sample we used, that could be extended and diversified (including respondents from other universities). The studied sample could be expanded and further research could also test the perspective of tourism managers as a way of determining the existent gap between the expectations of students related to CSR practices and the practical state of CSR implementation in tourism.

All scales of measurement used for the 8 sub-dimensions of size "Medium" are reliable, the Cronbach alpha coefficient values exceeding the minimum allowable limit of 0.7. For each sub-dimension, there are strong correlations between items analysed. These results have enabled a confirmatory factor analysis. Also, all values exceed the minimum allowable load factor of 0.4 .

Regarding the possible subjectivity associated to the questionnaire technique, this of course cannot be completely eliminated, but we took some specific measures to lower this risk: we assured the respondents about the confidentiality of their responses, that their identity will not be exposed and that the results of our research will only be presented in an aggregate manner at the level of the sample of our study.

Future research directions might take into account other CSR dimensions (i.e., human resources) or the magnitude of strategic approach of CSR in the hotel and tourism industry and the effect on students in their decision-making process of getting a job in tourism.

Author Contributions: Diana Corina GLIGOR-CIMPOIERU (first and corresponding author) is a PhD Lecturer, and her research and practical expertise is focused mainly on business ethics and CSR topics, with an emphasis on the importance of a strategic approach to CSR. She reviewed relevant literature for the article, along with the rest of the research team she designed the research methodology and the used questionnaire, monitored data collection, interpreted obtained results and completed the final version of the paper. Valentin Partenie MUNTEANU (second author) is a PhD Assistant Professor and Director of the Management Department; he is specialized in business ethics and project management. He also reviewed relevant literature, was involved in elaborating research 
methodology and questionnaire, supervised data collection, interpreted results and coordinated the actions of the entire research team. Renata Dana NIOȚU-ANTONIE (third author) is a PhD Assistant Professor and Director of the Marketing and International Economic Relations Department with a keen interest in entrepreneurship from European and international perspective. She reviewed relevant literature, contributed to the design of the research methodology and questionnaire, monitored data collection and interpreted results. Andreia SCHNEIDER (fourth author) is a PhD Lecturer and her main expertise topics are: management and leadership in the hospitality industry, initiating and developing projects on ecological education and environmental protection. She reviewed relevant literature, contributed to the design of the used research methodology and questionnaire, collected data and interpreted results. Gheorghe PREDA (fifth author) is a PhD Lecturer, and his main research interests are related to strategic marketing and strategic innovation in marketing. He contributed to the design of the research methodology and statistically analysed the collected data for this research. All authors wrote the manuscript and approved its final version.

Conflicts of Interest: The authors declare no conflict of interest.

\section{References}

1. Coles, T.; Fenclova, E.; Dinan, C. Tourism and corporate social responsibility: A critical review and research agenda. Tour. Manag. Perspect. 2013, 6, 122-141. [CrossRef]

2. Merwe, M.V.D.; Wöcke, A. An investigation into responsible tourism practices in the South African hotel industry. S. Afr. J. Bus. Manag. 2007, 38, 1-15.

3. Wells, V.K.; Gregory Smith, D.; Taheri, B.; Manika, D.; McCowlen, C. An exploration of CSR development in heritage tourism. Ann. Tour. Res. 2016, 58, 1-17. [CrossRef]

4. Krambia-Kapardis, M.; Neophytidou, C. CSR Reporting in the Hotel Industry. In Proceedings of the 4thInternational Conference on Tourism and Hospitality Management, Athens, Greece, 19-21 June 2014; pp. 145-157. Available online: http://dratte.gr/DRATTE/Acad._conferences.html (accessed on 28 November 2016).

5. Shin, I.; Hur, W.M.; Kang, S. Employees' perceptions of corporate social responsibility and job performance: A sequential mediation model. Sustainability 2016, 8, 493. [CrossRef]

6. Timothy, D.J.; Timothy, D.; Teye, V. Tourism and the Lodging Sector; Routledge, Elsevier: Burlington, VT, USA, 2009.

7. Adlwarth, W. Corporate social responsibility-customer expectations and behaviour in the tourism sector. Trends Issues Glob. Tour. 2010, 2010, 101-109.

8. Levy, S.E.; Duverger, P. Consumer perceptions of sustainability in the lodging industry: Examination of sustainable tourism criteria. In Proceedings of the International CHRIE Conference-Refereed Track, Amherst, MA, USA, 28-31 July 2010; pp. 2-8. Available online: http://lib.dtc.ac.th/research/0028.pdf (accessed on 28 November 2016).

9. Han, H.; Hsu, L.T.J.; Lee, J.S.; Sheu, C. Are lodging customers ready to go green? An examination of attitudes, demographics, and eco-friendly intentions. Int. J. Hosp. Manag. 2011, 30, 345-355. [CrossRef]

10. Kang, K.H.; Stein, L.; Heo, C.Y.; Lee, S. Consumers' willingness to pay for green initiatives of the hotel industry. Int. J. Hosp. Manag. 2012, 31, 564-572. [CrossRef]

11. Gordon, K. The OECD Guidelines and Other Corporate Responsibility Instruments; OECD Working Papers on International Investment, OECD Publishing: Paris, France, 2001. Available online: http:/ / dx.doi.org/10. $1787 / 302255465771$ (accessed on 28 November 2016).

12. Ayuso, S. Adoption of voluntary environmental tools for sustainable tourism: Analysing the experience of Spanish hotels. Corp. Soc. Responsib. Environ. Manag. 2006, 13, 207-220. [CrossRef]

13. De Grosbois, D. Corporate social responsibility reporting by the global hotel industry: Commitment, initiatives and performance. Int. J. Hosp. Manag. 2012, 31, 896-905. [CrossRef]

14. Simões, P.; Carvalho, P.; Marques, R.C. Performance assessment of refuse collection services using robust efficiency measures. Resour. Conserv. Recycl. 2012, 67, 56-66. [CrossRef]

15. Camilleri, M. Advancing the Sustainable Tourism Agenda through Strategic CSR Perspectives. Tour. Plan. Dev. 2014, 11, 42-56. [CrossRef]

16. Oliveira, R.; Pedro, M.I.; Marques, R.C. Cost efficiency of Portuguese hotels in the Algarve: A comparative analysis using mathematical and econometric approaches. Tour. Econ. 2014, 20, 797-812. [CrossRef]

17. Siu-wa Chan, E. Green Marketing: Hotel Customers' Perspective. J. Travel Tour. Mark. 2014, 31, 915-936. [CrossRef] 
18. Fatma, M.; Rahman, Z.; Khan, I. Measuring consumer perception of CSR in tourism industry: Scale development and validation. J. Hosp. Tour. Manag. 2016, 27, 39-48. [CrossRef]

19. Kim, S.B.; Kim, D.Y. Antecedents of Corporate Reputation in the Hotel Industry: The Moderating Role of Transparency. Sustainability 2017, 9, 951. [CrossRef]

20. Sobczak, A.; Debucquet, G.; Havard, C. The impact of higher education on students' and young managers' perception of companies and CSR: An exploratory analysis. Corp. Gov. Int. J. Bus. Soc. 2006, 6, 463-474. [CrossRef]

21. Wong, A.; Long, F.; Elankumaran, S. Business students' perception of corporate social responsibility: The United States, China, and India. Corp. Soc. Responsib. Environ. Manag. 2010, 17, 299-310. [CrossRef]

22. Evans, W.R.; Davis, W.D. An Examination of Perceived Corporate Citizenship, Job Applicant Attraction, and CSR Work Role Definition. Bus. Soc. 2011, 50, 456-480. [CrossRef]

23. Burcea, M.; Marinescu, P. Students' perceptions on corporate social responsibility at the academic level. Case study: The Faculty of Administration and Business, University of Bucharest. Amfiteatrul Econ. 2011, 13, 207-220.

24. Del Mar Alonso-Almeida, M. Environmental management in tourism: Students' perceptions and managerial practice in restaurants from a gender perspective. J. Clean. Prod. 2013, 60, 201-207. [CrossRef]

25. Fitzpatrick, J.; Cheng, J. An investigation of United States and Hong Kong business students' perceptions of corporate social responsibility. J. Acad. Bus. Ethics 2014, 8, 1-20.

26. Yilmazdogan, O.C.; Cihan, S.; Cicek, D. The Effect of Corporate Social Responsibility (CSR) Perception on Tourism Students' Intention to Work in Sector. Procedia Econ. Financ. 2015, 23, 1340-1346. [CrossRef]

27. Barrena-Martinez, J.; Lopez-Fernandez, M.; Marquez-Moreno, C.; Romero-Fernandez, P.M. Attitudes of University Students Regarding Potential Conflicts in Socially Responsible Companies. J. Hum. Values 2016, 22, 125-138. [CrossRef]

28. European Commission. EU Ecolabel for Tourist Accommodation Criteria. July 2009. Available online: http:/ / ec.europa.eu/environment/ecolabel/documents/hotels.pdf (accessed on 31 March 2016).

29. Nunnally, J. Psychometric Methods; McGraw-Hill: New York, NY, USA, 1978.

30. Field, A. Discovering Statistics Using SPSS; Sage Publications: New York, NY, USA, 2009.

(C) 2017 by the authors. Licensee MDPI, Basel, Switzerland. This article is an open access article distributed under the terms and conditions of the Creative Commons Attribution (CC BY) license (http:/ / creativecommons.org/licenses/by/4.0/). 